\title{
CORRELATION OF PERITUMORAL BRAIN EDEMA WITH MORPHOLOGICAL CHARACTERISTICS AND KI67 PROLIFERATIVE INDEX IN RESECTED INTRACRANIAL MENINGIOMAS
}

\author{
Hakija Bečulić ${ }^{1}$, Rasim Skomorac ${ }^{1}$, Aldin Jusić ${ }^{1}$, Fahrudin Alić ${ }^{1}$, Anes Mašović ${ }^{1}$, \\ Eldin Burazerović2 ${ }^{2}$ Ibrahim Omerhodžić ${ }^{2}$, Mirsad Dorić3 ${ }^{3}$, Melica Imamović4, \\ Alma Mekić-Abazović ${ }^{5}$, Alma Efendić ${ }^{6}$ and Dalma Udovčić-Gagula ${ }^{7}$
}

${ }^{1}$ Department of Neurosurgery, Zenica Cantonal Hospital, Zenica, Bosnia and Herzegovina; ${ }^{2}$ Department of Neurosurgery, Sarajevo University Hospital Centre, Sarajevo, Bosnia and Herzegovina;

${ }^{3}$ Institute of Pathology, Medical Faculty of Sarajevo, Sarajevo, Bosnia and Herzegovina; ${ }^{4}$ Department of Emergency Medicine, Zenica Cantonal Hospital, Zenica, Bosnia and Herzegovina; ${ }^{5}$ Department of Oncology and Radiotherapy, Zenica Cantonal Hospital, Zenica, Bosnia and Herzegovina;

${ }^{6}$ Department of Radiology, Zenica Cantonal Hospital, Zenica, Bosnia and Herzegovina; ${ }^{7}$ Institute of Pathology, Sarajevo University Hospital Centre, Sarajevo, Bosnia and Herzegovina

SUMMARY - The aim of the study was to analyze correlation between morphological characteristics of intracranial meningiomas and Ki67 labeling index (Ki67 LI), and their influence on peritumoral brain edema (PTBE). There were 41 consecutive patients with intracranial meningiomas surgically treated at the Department of Neurosurgery, Zenica Cantonal Hospital, Zenica, Bosnia and Herzegovina, during the period from January 2010 to December 2015. We reviewed clinical data including patient age, gender, magnetic resonance imaging (MRI) characteristics of the tumor and peritumoral edema, tumor margins, intraoperative characteristics, histopathologic grade and Ki67 LI. In all cases, follow up MRI was obtained at about three months after resection and PTBE was analyzed. Our research showed the tumor volume, tumor margins, and intraoperative signs of arachnoidal and pial invasion to be associated with PTBE in intracranial meningiomas. Ki67 LI expression correlated with PTBE. This study showed the resolution of PTBE to depend on invasive behavior of meningioma and KI67 LI. PTBE, pial/cortical and arachnoidal invasion significantly influence the extent of surgical resection.

Key words: Meningioma; Meningeal neoplasms; Brain edema; Cell proliferation; Ki-67 antigen

\section{Introduction}

Meningiomas are the most common non-glial intracranial tumors, which account for $14 \%-19 \%$ of all intracranial lesions ${ }^{1}$. They are mostly benign tumors ${ }^{2}$. According to the World Health Organization (WHO)

Correspondence to: Hakija Bečulic, MD, Department of Neurosurgery, Zenica Cantonal Hospital, Crkvice 67,72 000 Zenica, Bosnia and Herzegovina

E-mail: dr_beculichakija@hotmail.com

Received February 8, 2017, accepted April 12, 2018 classification, meningiomas are classified into three histologic grades: benign, atypical and malignant ${ }^{3}$. Peritumoral brain edema (PTBE) is formed in 40\%$78 \%$ of all cases of intracranial meningiomas. PTBE may vary in shape and size, and sometimes can be two to three times higher than the tumor. PTBE causes increase in intracranial pressure and a higher incidence of postoperative complications ${ }^{4}$. The precise pathophysiology of PTBE is not clearly understood. There are several factors directly included in PTBE pathophysiology such as tumor size, localization, venous 
thrombosis, histologic grade, sex hormone receptor expression, vascularization, growth factor expression, microcortical invasion, etc. ${ }^{4,5}$. About 95\%-97\% of meningiomas are slow growing tumors (grades I and II). Large meningiomas cause significant compression of brain veins and contribute to increasing $\mathrm{PTBE}^{1,5}$. Some studies indicate positive correlation between Ki67 labeling index (Ki67 LI) and PTBE, such as type of vascularization, microcortical and pial invasion and $\mathrm{PTBE}^{4,5}$.

This prospective study analyzed correlation between PTBE and neuroradiological characteristics, intraoperative findings and Ki67 LI. The aim of this study was to investigate correlation between morphological characteristics of intracranial meningiomas and Ki67 LI, and their influence on PTBE.

\section{Patients and Methods}

\section{Study design}

This prospective study included 41 consecutive patients with intracranial meningiomas surgically treated at the Department of Neurosurgery, Zenica Cantonal Hospital, Zenica, Bosnia and Herzegovina, during the period from January 2010 to December 2015. All patients underwent magnetic resonance imaging (MRI) before the surgery. In all cases, we diagnosed solitary meningioma. We reviewed clinical data including patient age, gender, MRI characteristics of the tumor and peritumoral edema, tumor margins, intraoperative characteristics, histopathologic grade and Ki67 LI. In all cases, follow up MRI was performed at three months after resection and PTBE was analyzed.

\section{Imaging}

In this study, we used MRI to analyze imaging characteristics of the tumor and PTBE. In all patients, preoperative and postoperative MRI was performed using 1.5 T machine (Siemens Magnetom Avanto 1.5 T). All patients underwent MRI within 30 days before tumor resection. Tumor volume was measured using the formula for spheroid $(V=4 / 3 \pi \times \mathrm{a} a / 2 \mathrm{xb} / 2 \mathrm{x} \mathrm{c} / 2)^{6}$. Tumor volume and PTBE were measured using the same formula. We analyzed the relationship between tumor and PTBE using edema index (EI). The formula for $\mathrm{EI}$ is: $\mathrm{EI}=(\mathrm{V}$ tumor + edema $) /(\mathrm{V}$ tumor $)$. If there is no edema, $\mathrm{EI}=1^{1,6}$. Tumor size was measured using T1-weighted MRI scans with gadolinium, but PTBE was evaluated on T2-weighted scans. Tumor volume was measured in three maximal diameters using axial, sagittal and coronal scans. The volumes of tumor and PTBE were measured using maximal perpendicular diameters ( $a$ and $b$ ) on axial scans, and coronal diameter (c) on coronal or sagittal scans ${ }^{6}$. To measure these morphological characteristics we used IMPAX system (Impax version 6.5.1.144, AGFA HealthCare N.V., CE 0213). All patients had postoperative follow up. About three months after the operation, we performed postoperative MRI to analyze the presence or absence of PTBE. We compared these data with preoperative findings.

\section{Inclusion criteria}

All patients included in the study had solitary meningiomas. These patients were surgically treated at the Department of Neurosurgery, Zenica Cantonal Hospital by microneurosurgical resection.

\section{Exclusion criteria}

Patients with multiple meningiomas and other additional tumors were excluded from this study. Patients with relapsing or recurrent meningiomas were also excluded.

\section{Surgical findings}

All patients were surgically treated at the same neurosurgical department. The surgery was performed in optimal conditions in all patients using neurosurgical microscope (Carl Zeiss, OPMI VARIO/NC 33). We analyzed tumor location, presence of pial invasion, and signs of dural, bone and sinus invasion. The extent of tumor resection was noted using Simpson grading system: grade I - complete removal of tumor with excision of its dural attachment and any abnormal bone including resection of venous sinus if involved; grade II complete tumor removal with coagulation of its dural attachment; grade III - complete tumor removal of intradural tumor without resection or coagulation of its dural attachment or extradural extension; grade IV partial tumor removal, leaving intradural tumor in situ; and grade $\mathrm{V}$ - decompression with or without biopsy?

\section{Histopathology}

After tumor resection, histopathologic and immunohistochemical analysis was performed. In this anal- 
Table 1. Preoperative tumor volume

\begin{tabular}{|l|l|l|l|l|l|l|l|}
\hline \multirow{2}{*}{$\mathrm{N}$} & \multirow{2}{*}{ Mean } & \multirow{2}{*}{ SD } & \multirow{2}{*}{ SE } & \multicolumn{2}{l|}{ 95\% CI for mean } & \multirow{2}{*}{ Minimum } & \multirow{2}{*}{ Maximum } \\
\cline { 5 - 7 } & & & & Lower limit & Upper limit & & \\
\hline 41 & 27.81 & 28.65 & 4.47 & 19.04 & 36.58 & 1.24 & 130 \\
\hline
\end{tabular}

$\mathrm{SD}=$ standard deviation; $\mathrm{SE}=$ standard error $; 95 \% \mathrm{CI}=95 \%$ confidence interval

Table 2. Edema index

\begin{tabular}{|l|l|l|l|l|l|l|l|}
\hline \multirow{2}{*}{$\mathrm{N}$} & \multirow{2}{*}{ Mean } & \multirow{2}{*}{ SD } & \multirow{2}{*}{ SE } & 95\% CI for mean & \multirow{2}{*}{ Minimum } & \multirow{2}{*}{ Maximum } \\
\cline { 5 - 6 } & & & & Lower limit & Upper limit & & \multirow{2}{*}{ Mimu } \\
\hline 41 & 4.87 & 4.19 & 0.65 & 3.58 & 6.15 & 1 & 14 \\
\hline
\end{tabular}

$\mathrm{SD}=$ standard deviation; $\mathrm{SE}=$ standard error; $95 \% \mathrm{CI}=95 \%$ confidence interval

ysis, Ki67 LI was measured. Tissues were obtained from formalin-fixed (4\%), paraffin-embedded blocks cut into 3-5 $\mu \mathrm{m}$ sections. All sections were mounted on poly-L-lysine coated slides and left in a $45^{\circ} \mathrm{C}$ incubator overnight before staining. The slides were deparaffinized in xylene and rehydrated with a series of decreasing ethanol concentrations and finally distilled water. Antigen retrieval was performed immersing the slides in a thermostat bath with preheated $10 \mathrm{mmol} / \mathrm{L}$ citrate buffer ( $\mathrm{pH} \mathrm{6.0)}$ for 40 minutes at $97{ }^{\circ} \mathrm{C}$, and after that cooled at room temperature for 20 minutes. Then the slides were treated with $3.0 \% \mathrm{H}_{2} \mathrm{O}_{2}$ in distilled water for 10 minutes, to block endogenous peroxidase activity. After blocking nonspecific antigen with normal rabbit serum for 10 minutes, the slides were incubated for 30 minutes at room temperature with anti-human Ki-67 antibody (1:200; Clone MIB1, Code M7240; Dako, Glostrup, Denmark). Negative controls were obtained by omitting the primary antibody. Only definite nuclear staining was regarded as positive. Cases were scored by the percentage of tumor cells that stained, determined in more visual fields with the most intense staining (hot spot).

\section{Statistical analysis}

All data were collected and processed using the Microsoft Excel version 2010. In this research, we used descriptive and comparative statistics methods. Of the descriptive statistical methods we used percentages, mean, standard deviation (SD), minimum, maximum, and $95 \%$ confidence interval $(95 \% \mathrm{CI})$ with upper and lower limits. Of the comparative statistical methods we used the methods of nonparametric data: $\chi^{2}$-test and the method of comparing parametric data (t-test), with $95 \% \mathrm{CI}$ of statistical significance.

\section{Results}

\section{Patient characteristics}

This prospective study included 41 consecutive patients with intracranial meningioma surgically treated at the Department of Neurosurgery, Zenica Cantonal Hospital, Zenica, of which 17 (41.57\%) were males and $24(58.53 \%)$ females. The mean age of male and female patients was $65.66 \pm 11.248$ and $61.083 \pm 9.541$, respectively, without any statistically significant differences between males and females $(t=1.190 ; p=0.120)$.

\section{Tumor volume and peritumoral brain edema}

All patients underwent MRI 1.5 T before the surgery. To measure morphological characteristics of meningiomas, we used IMPAX system at Zenica Cantonal Hospital. Tumor volume and PTBE were measured using the formula for spheroid ( $V=4 / 3 \pi \mathrm{x}$ a $/ 2 \mathrm{x}$ $\mathrm{b} / 2 \mathrm{x}$ c/2). Tumor size was measured using T1-weighted MRI scans with gadolinium. Tumor volume was measured in three maximal diameters using axial (a), sagittal (b) and coronal scans (c) ${ }^{6}$ (Table 1). Comparison of tumor volume between male and female patients did not yield any statistically significant differences ( $t=-1.479 ; p=0.071)$.

The relationship between tumor and PTBE was analyzed using edema index (EI). The formula for EI is: $\mathrm{EI}=(\mathrm{V}$ tumor + edema $) /(\mathrm{V} \text { tumor })^{1,6}$. $\mathrm{PTBE}$ was evaluated on T2-weighted scans (Table 2 ). 


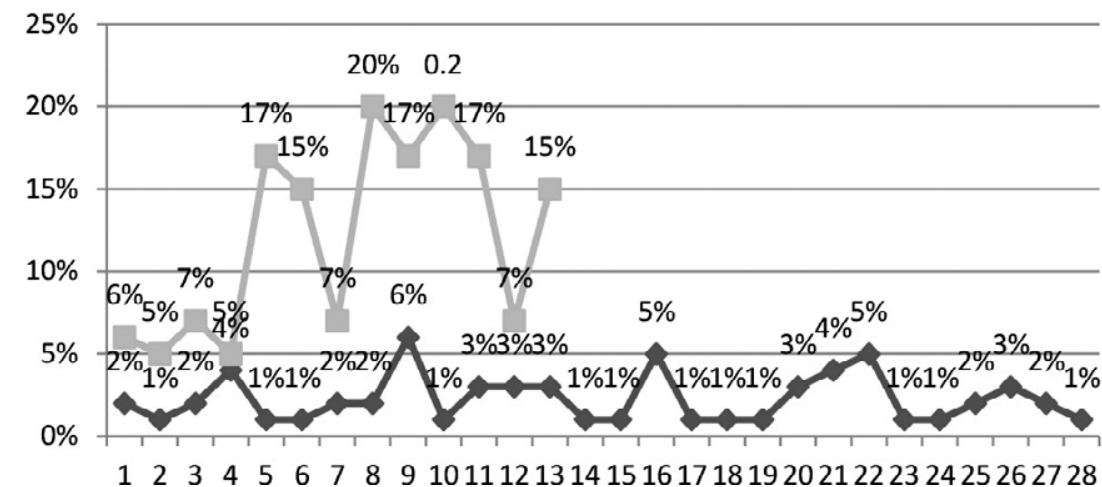

Fig. 1. Correlation of tumor margins and Ki67 LI.

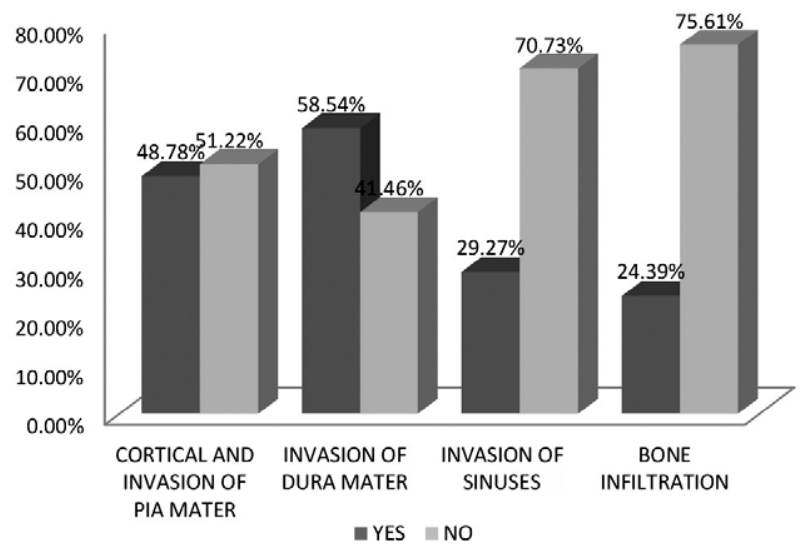

Fig. 2. Pial, dural and sinus invasion and bone infiltration.

We analyzed EI in males and females and found no statistically significant differences between these groups $(t=-0.166 ; p=0.434)$.

\section{Tumor margins}

Tumor margins were evaluated using MRI 1.5 T with gadolinium and defined as regular or irregular. Regular margins were verified in $28(68.30 \%)$ and irregular margins in 13 (31.70\%) cases. Precise statistical analysis showed strong correlation of pial invasion $\left(\chi^{2}=14.43 ; p=3.84\right)$, dural invasion $\left(\chi^{2}=13.48 ; p=3.84\right)$ and bone infiltration $\left(\chi^{2}=14.24 ; \mathrm{p}=3.84\right)$ with tumor margins. There was no correlation between tumor margins and sinus invasion $\left(\chi^{2}=0.77 ; p=3.84\right)$. We used t-test to compare tumor margins and Ki67 LI (Fig. 1). In a statistically significant number of patients, irregular margins were associated with higher Ki67 ( $t=-6.05$; $\mathrm{p}<0.00001)$. Precise statistical analysis showed a statis- tically significant correlation between the appearance of tumor margins and EI. In a statistically significant number of patients, irregular margins were associated with higher EI $(t=-8.93 ; \mathrm{p}<0.00001)$.

\section{Intraoperative findings}

All patients included in this study were surgically treated at Department of Neurosurgery, Zenica Cantonal Hospital. Surgical findings such as pial invasion, dural invasion, sinus invasion, bone infiltration and degree of resection according to Simpson scale were evaluated. Pial invasion was found in 20 (48.78\%), dural invasion in 24 (58.54\%), sagittal or another sinus invasion in $12(29.27 \%)$ and bone infiltration in 10 (24.39\%) patients (Fig. 2).

We analyzed pial, dural and sinus invasion, as well as bone infiltration in relation to gender. There was no statistical significance in pial $\left(\chi^{2}=0.034 ; p=3.84\right)$, dural $\left(\chi^{2}=0.001 ; \mathrm{p}=3.84\right)$ and sinus invasion $\left(\chi^{2}=0.509\right.$; $\mathrm{p}=3.84)$ according to gender. There was no statistical significance in bone infiltration according to gender either $\left(\chi^{2}=0.716 ; p=3.84\right)$.

Invasive characteristics of meningiomas correlated with EI. We found statistical significance in pial $\left(\chi^{2}=15.760 ; \mathrm{p}=5.99\right)$ and dural invasion $\left(\chi^{2}=9.870\right.$; $\mathrm{p}=5.99)$ in relation to EI. There was no statistical significance in sinus invasion according to EI $\left(\chi^{2}=4.043\right.$; $\mathrm{p}=5.99)$. We found statistical significance between bone infiltration and EI $\left(\chi^{2}=9.676 ; p=5.99\right)$. The extent of meningioma resection was classified according to Simpson classification. In 26 (63.41\%) patients, we performed complete tumor removal (grade I), in 13 (31.71\%) complete tumor removal with coagulation of dural attachment (grade II), and in two (4.88\%) patients 
Table 3. Grade of resection in relation to edema index

\begin{tabular}{|c|c|c|c|c|c|c|c|c|}
\hline \multirow{2}{*}{ Simpson } & \multirow{2}{*}{$\mathrm{n}$} & \multirow{2}{*}{ Mean } & \multirow{2}{*}{$\mathrm{SD}$} & \multirow{2}{*}{$\mathrm{SE}$} & \multicolumn{2}{|c|}{$95 \%$ CI for mean } & \multirow{2}{*}{ Minimum } & \multirow{2}{*}{ Maximum } \\
\hline & & & & & Lower limit & Upper limit & & \\
\hline Grade I & 26 & 3.680 & 3.541 & 0.694 & 2.319 & 5.042 & 1 & 12 \\
\hline Grade II & 13 & 6.692 & 4.661 & 1.292 & 4.16 & 9.226 & 1 & 14 \\
\hline Grade III & 2 & 8.5 & 4.949 & 6.010 & -3.28 & 20.28 & 5 & 12 \\
\hline
\end{tabular}

$\mathrm{SD}=$ standard deviation; $\mathrm{SE}=$ standard error $; 95 \% \mathrm{CI}=95 \%$ confidence interval

Table 4. Grade of meningiomas and edema index

\begin{tabular}{|l|l|l|l|l|l|l|l|l|}
\hline \multirow{2}{*}{ Tumor grade } & \multirow{2}{*}{$\mathrm{n}$} & \multirow{2}{*}{ Mean } & \multirow{2}{*}{$\mathrm{SD}$} & \multirow{2}{*}{$\mathrm{SE}$} & \multicolumn{2}{|l|}{ 95\% CI for mean } & \multirow{2}{*}{ Minimum } & \multirow{2}{*}{ Maximum } \\
\cline { 6 - 8 } & & & & & Lower limit & Upper limit & & \\
\hline Grade I & 34 & 3.755 & 3.517 & 0.603 & 2.57 & 4.93 & 1 & 14 \\
\hline Grade II & 6 & 10 & 3.033 & 1.238 & 7.57 & 12.42 & 4 & 12 \\
\hline Grade III & 1 & 12 & & & & & & \\
\hline
\end{tabular}

$\mathrm{SD}=$ standard deviation; $\mathrm{SE}=$ standard error $; 95 \% \mathrm{CI}=95 \%$ confidence interval

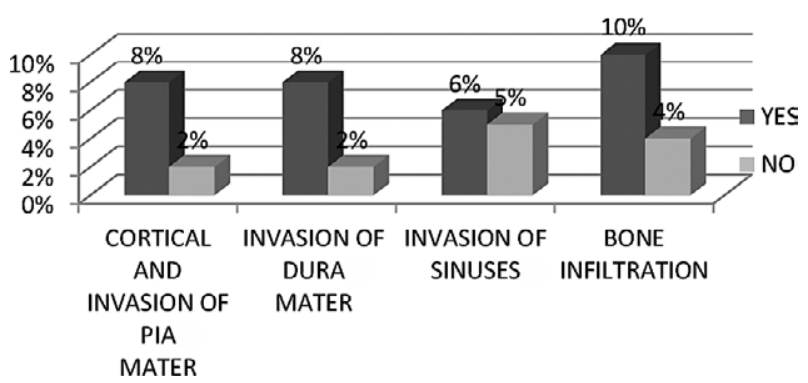

Fig. 3. Correlation of Ki67 LI with pial, dural and sinus invasion, and bone infiltration.

we performed complete tumor removal with preservation of dural attachment. We found statistical significance between the extent of resection and EI $(\mathrm{t}=-2.505$; $\mathrm{p}=0.008)$. Greater EI was associated with difficulty on surgical removal of meningiomas (Table 3).

\section{Histopathology and Ki67 LI}

According to the WHO, meningiomas are classified as grade I (benign), grade II (atypical) and grade III (malignant). We compared histologic grade of tumors with EI and found statistical significance ( $\mathrm{t}=-$ 4.577; $\mathrm{p}=0.0002$ ) (Table 4).

In all tumors, Ki67 LI was analyzed. In our patients, minimal and maximal Ki67 was $1 \%$ and 20\% (mean 5\%). There was no statistically significant difference between males and females according to Ki67LI
Table 5. Peritumoral brain edema (PTBE) on follow up magnetic resonance (MRI) of brain (three months after tumor removal)

\begin{tabular}{|l|l|l|}
\hline Postoperative MRI & $\mathrm{n}$ & $\%$ \\
\hline PTBE absent & 25 & 60.98 \\
PTBE present & 16 & 39.02 \\
\hline
\end{tabular}

$(t=-0.742 ; p=0.231)$. The value of Ki67 LI was compared with intraoperative characteristics of tumors.

We found statistical significance comparing Ki67 LI with pial invasion $\left(\chi^{2}=8.042 ; \mathrm{p}=7.82\right)$, but not with $\operatorname{dural}\left(\chi^{2}=6.940 ; p=7.82\right)$ and sinus $\left(\chi^{2}=0.826 ; p=7.82\right)$ invasion. Comparison of Ki67 LI and bone infiltration yielded statistical significance $\left(\chi^{2}=8.916 ; p=7.82\right)$ (Fig. 3). Higher Ki67 LI was associated with invasive behavior of meningiomas.

\section{Postoperative MRI}

Three months after tumor removal, all patients underwent follow-up MRI 1.5 T. Twenty-five (60.98\%) patients were free from edema, whereas in 16 (39.02\%) patients edema was present three months after tumor removal (Table 5).

In this study, we compared pial/cortical invasion, dural invasion, venous sinus invasion, bone infiltration and postoperative PTBE. The presence of postoperative PTBE was associated with cortical/pial invasion 
$\left(\chi^{2}=15.74 ; p=3.84\right)$, dural invasion $\left(\chi^{2}=9.06 ; p=3.84\right)$ and bone infiltration $\left(\chi^{2}=9.33 ; \mathrm{p}=3.84\right)$, but not with venous sinus invasion $\left(\chi^{2}=0.86 ; p=3.84\right)$.

\section{Discussion}

Meningiomas are the most common non-glial intracranial tumors. They arise from arachnoid cap cells ${ }^{2}$. The incidence of meningiomas is 2:100 000 in adults. There is an approximate 3:1 female predominance ${ }^{7}$. Meningiomas account for 14\%-19\% of all primary intracranial tumors in adults and occur most commonly in females ${ }^{1}$. In our research, meningiomas were also more common in females. The incidence of incidental meningiomas was $2 \%-3 \%$ in an autopsy series ${ }^{8}$. The $\mathrm{WHO}$ classifies meningiomas into three groups: benign (grade I), atypical (grade II) and malignant (grade III) ${ }^{1}$.

The mean age of our patients was $62.658 \pm 10.118$. The incidence of meningiomas is rising with age. They are most commonly found in the $6^{\text {th }}$ and $7^{\text {th }}$ decades of life, which corresponds to our results 9 .

In our study, the mean tumor volume was $27.81 \mathrm{~cm}^{3}$ without significant differences between males and females. Some studies found no statistically significant correlation between tumor volume and $\mathrm{PTBE}^{10,11}$, but some papers report on strong correlation between tumor volume and $\mathrm{PTBE}^{6,8}$. Some tumors caused significant venous compression and ischemic stroke and significant brain edema ${ }^{12}$. In most cases, we found large tumors with significant PTBE. The results of this study showed a statistically significant correlation between tumor volume and PTBE. In our research, larger tumors were associated with significant PTBE and higher EI.

Tumor margins were defined as regular or irregular. Many studies showed correlation between irregular tumor margins and significant $\mathrm{PTBE}^{13-15}$. In our study, 12 (29.26\%) tumors had irregular margins and were associated with higher EI. We found strong correlation between EI and presence of irregular tumor margins. Some studies showed that tumors with irregular margins caused dural, pial and cortical invasion ${ }^{6,16,17}$. Our study revealed correlation between these parameters and EI, but no significant correlation of EI with venous sinus invasion or bone infiltration.

Meningiomas are slow growing tumors that cause compression of adjacent brain, but some meningiomas destroy leptomeninges and can cause cortical invasion. Leptomeninges around the tumor margins are a phys- iological barrier of the adjacent brain ${ }^{18,19}$. The arachnoid plane is part of the blood brain barrier and protects brain from the formation of edema ${ }^{4-6}$. Pia is permeable for water and electrolytes but not for plasma proteins. Cerebral cortex is not permeable. Leptomeningeal and cortical disruption increases vascular permeability ${ }^{20}$. Plasma proteins and water flow into the white matter and cause edema ${ }^{6}$. The results of this and other studies contribute to these data ${ }^{20-22}$. In 1957 , Simpson introduced the system for evaluation of the extent of meningioma resection: grade I - complete removal of tumor with excision of its dural attachment and any abnormal bone including resection of venous sinus if involved; grade II - complete tumor removal with coagulation of its dural attachment; grade III complete tumor removal of intradural tumor without resection or coagulation of its dural attachment or extradural extension; grade IV - partial tumor removal, leaving intradural tumor in situ; and grade $\mathrm{V}$ - decompression with or without biopsy ${ }^{7}$. Some studies showed that meningiomas with higher PTBE, irregular margins and invasive behavior were associated with higher Simpson grade ${ }^{6,23}$. In our study, we found significant correlation between the extent of resection and EI. The tumors with regular margins, without invasive behavior and lowest EI were easier for resection.

This research showed strong correlation between histologic grade of meningiomas and EI. Our results correspond to the literature ${ }^{6,24}$.

Numerous studies showed association between Ki67 LI and PTBE, as well as between Ki67 LI and invasive behavior of meningiomas. Meningiomas with higher Ki67 LI lead to a higher frequency of PTBE ${ }^{6,14}$. Our study showed significant correlation between Ki67 LI and EI, consistent with the literature ${ }^{6}$. We found a statistically significant correlation between Ki67 LI and pial/cortical and arachnoidal invasion. These results are also consistent with the literature ${ }^{6,16,17}$.

In this study, we analyzed the presence PTBE two to three months after surgical resection. Precise statistical analysis yielded strong correlation between postoperative PTBE and Ki67 LI, as well as between invasive behavior of meningiomas and postoperative PTBE. According to these results, resolution of PTBE depends on proliferative characteristics and invasive behavior of intracranial meningiomas. Whatever, aggressive and invasive meningiomas caused slow resolution of PTBE. This is an important characteristic of meningiomas not dependent on tumor grade. 


\section{Conclusion}

Our research showed tumor volume, margins, intraoperative signs of arachnoidal and pial invasion to be associated with PTBE in intracranial meningiomas. Ki67 LI was associated with PTBE. These are significant factors influencing PTBE formation in meningiomas. According to the results of our study, resolution of PTBE is dependent on invasive behavior of meningioma and KI67 LI. PTBE, pial/cortical and arachnoidal invasion have a significant influence on the extent of surgical resection.

\section{References}

1. Byung-Won K, Min-Su K, Sang-Woo K, Chul-Hoon C, Oh-Lyong K. Peritumoral brain edema in meningiomas: correlation of radiologic and pathologic features. J Korean Neurosurg Soc. 2011;49:26-63, https://doi.org/10.3340/jkns.2011.49.1.26

2. Marković M, Antunović V, Milenković, Živković N. Prognostic value of peritumoral edema and angiogenesis in intracranial meningioma surgery. JBUON. 2013;18(2):430-6.

3. Ketter R, Rahnenführer J, Henn W, Yoo-Jin K, Feiden W, Wolf-Ingo S, Zang KD, Urbschat S. Correspondence of tumor localisation with tumor recurrence and cytogenetic progression in meningiomas. Neurosurgery. 2008;62:61-70, doi: 10.1227/01.NEU.0000311062.72626.D6

4. Mattei TA, Mattei JA, Ramina R, Aguiar PH, Plese JP, Marino P. Edema and malignancy in meningiomas. Clinics. 2005;60: 201-6, https://dx.doi.org/10.1590/S1807-59322005000300004

5. Nassehi D. Intracranial meningiomas, the VEGF-A pathway and peritumoral brain edema. Dan Med J. 2013;60:B4626.

6. Tamiya T, Ono Y, Matsumoto K, Ohmoto T. Peritumoral brain edema in intracranial meningiomas: effects of radiological and histological factors. Neurosurgery. 2001;49:1046-52.

7. Violaris K, Katsarides V, Sakellariou P. The recurrence rate in meningiomas: analysis of tumor location, histological grading, and extent of resection. Open J Modern Neurosurg. 2012;2: 6-10, https://dx.doi.org/10.4236/ojmn.2012.21002

8. Kasuya H, Kubo O, Tanaka M, Amano K, Kato K, Hori T. Clinical and radiological features related to growth potential of meningioma. Neurosurg Rev. 2006;29:293-7, doi: 10.1007/ s10143-006-0039-3

9. Gurkanlar D, Er U, Sanli M, Özkan M, Sekerci Z. Peritumoral brain edema in intracranial meningiomas. J Clin Neurosci. 2005;12:750-3, http://dx.doi.org/10.1016/j.jocn.2004.09.029

10. Dolecek TA, Dressler EV, Thakkar JP, Liu M, Al-Qaisi A, Villano JL. Epidemiology of meningiomas post-Public Law 107-206: The Benign Brain Tumor. Cancer Registries Amendment Act. Cancer. 2015;121:2400-10, doi: 10.1002/cncr.29379

11. de Azambuja Pereira-Filho N, Pasqualotto Soares F, de Mello Chemale I, Barbosa Coutinho LM. Peritumoral brain edema in intracranial meningiomas. Arq Neuropsiquiatr. 2010;68:346-9, http://dx.doi.org/10.1590/S0004-282X2010000300003

12. Gawlitza M, Fiedler E, Schob S, Hoffmann KT, Surov A. Peritumoral brain edema in meningiomas depends on aquaporin-4 expression and not on tumor grade, tumor volume, cell count, or Ki-67 labeling index. Mol Imaging Biol. 2016;1-7, doi: 10.1007/s11307-016-1000-7

13. Bojić L, Ivanišević M, Rogošić $\mathrm{V}$, Galetović $\mathrm{D}$, Lešin M. Orbital meningiomas - clinical observation. Acta Clin Croat. 2007;46(1):7-11.

14. Alfotih G, Li FC, XU XK, Zhang SY. Factors associated with recurrence of postoperative meningioma: a clinical study of 138 patients. Rom Neurosurg. 2013;XX:379-87, https://doi.org/10.2478/romneu-2013-0021

15. Nakano T, Asano K, Miura H, Itoh S, Suzuki S. Meningiomas with brain edema: radiological characteristics on MRI and review of the literature. Clin Imaging. 2002;26:243-9.

16. Lee KJ, Joo WI, Rha HK, Park HK, Chough JK, Hong YK, Park CK. Peritumoral brain edema in meningiomas: correlations between magnetic resonance imaging, angiography, and pathology. Surg Neurol. 2008; 69:350-5, doi: 10.1016/j.surneu.2007.03.027

17. Ide M, Jimbo M, Kubo O, Yamamoto M, Takeyama E, Imanaga $H$. Peritumoral brain edema and cortical damage by meningioma. Brain Edema. 1994; IX:369-72, doi: 10.1007/9783-7091-9334-1_99

18. Rutka JT, Giblin J, Dougherty DV, McCulloch JR, De Armond SJ, Rosenblum ML. An ultrastructural and immunocytochemical analysis of leptomeningeal and meningioma cultures. J Neuropathol Exp Neurol. 1986; 45:285-303, https:// doi.org/10.1097/00005072-198605000-00012

19. Osawa T, Tosaka M, Nagaishi M, Yoshimoto Y. Factors affecting peritumoral brain edema in meningioma: special histological subtypes with prominently extensive edema. J Neurooncol. 2013;111:49-57, doi: 10.1007/s11060-012-0989-y

20. Hou J, Kshettry VR, Selman WR, Bambakidis NC. Peritumoral brain edema in intracranial meningiomas: the emergence of vascular endothelial growth factor-directed therapy. Neurosurg Focus. 2013;35: E2, doi: 10.3171/2013.8.FOCUS13301

21. Latini F, Larsson EM, Ryttlefors M. Rapid and accurate MRI segmentation of peritumoral brain edema in meningiomas. Clin Neuroradiol. 2015;1-8, doi:10.1007/s00062-015-0481-0

22. Simis A, de Aguiar PHP, Leite CC, Santana PA, Rosemberg S, Teixeira MJ. Peritumoral brain edema in benign meningiomas: correlation with clinical, radiologic, and surgical factors and possible role on recurrence. Surg Neurol. 2008;70:471-7, doi: 10.1016/j.surneu.2008.03.006

23. Sun Ha P, Chae-Yong K, Young Yim K, In Ae P, Min Seok K, Dong gyu K, Hee-Won J. Clinical study correlation of clinical and biological parameters with peritumoral edema in meningioma. J Neurooncol. 2002;60:235-45.

24. Shibuya M. Pathology and molecular genetics of meningioma: recent advances. Neurol Med Chir (Tokyo). 2015;55:14, doi: 10.2176/nmc.ra.2014-0233 
Sažetak

\title{
KORELACIJA PERITUMORALNOG EDEMA MOZGA S MORFOLOŠKIM KARAKTERISTIKAMA I KI67 PROLIFERACIJSKIM INDEKSOM KOD RESECIRANIH INTRAKRANIJSKIH MENINGEOMA
}

\author{
H. Bečulic, R. Skomorac, A. Jusic, F. Alic, A. Mašović, E. Burazerovic, I. Omerhodžic, M. Dorić, \\ M. Imamovic, A. Mekić-Abazović, A. Efendić i D. Udovčić-Gagula
}

Cilj studije je bio analizirati korelaciju između morfoloških karakteristika intrakranijskih meningeoma i Ki67 proliferacijskog indeksa, kao i njihovog odnosa s peritumoralnim edemom mozga. U studiju je bio uključen 41 konsekutivni bolesnik s intrakranijskim meningeomom koji su operativno liječeni u Službi za neurokirurgiju Kantonalne bolnice Zenica u razdoblju od siječnja 2010. do prosinca 2015. godine. U svrhu istraživanja analizirali smo kliničke podatke uključujući dob, spol, MRI karakteristike tumora i peritumoralnog edema, margine tumora, intraoperacijske karakteristike tumora, histopatološki gradus i Ki67. Kod svih bolesnika napravljen je kontrolni MRI mozga oko tri mjeseca nakon resekcije tumora. Na tim snimkama se analizirala moguća prisutnost peritumoralnog edema. Naše istraživanje je pokazalo da su volumen tumora, izgled njegovih margina, znaci arahnoidalne i pijalne invazije u korelaciji s veličinom peritumoralnog edema. Također, rezultati su pokazali da je rezolucija peritumoralnog edema ovisna o invazivnom ponašanju meningeoma i veličini Ki67. Peritumoralni edem, invazija pije/korteksa i arahnoideje značajno utječu na obim resekcije tumora.

Ključne riječi: Meningeom; Meningealni tumori; Moždani edem; Stanična proliferacija; Ki-67 antigen 